\title{
Efektivitas Kitosan Cangkang Keong Mas Dalam Mengendalikan Penyakit Yang Disebakan Virus Pada Tanaman Cabai(Capsicum annuum L)
}

\author{
*Doris Olviari Hamta, Asniwita, dan Novalina \\ Program Studi Magister Agroekoteknologi Universitas Jambi \\ *e-mail korespondensi : dorisolviari@gmail.com
}

\begin{abstract}
Chili is a herbaceous plant from the Solanaceae family. Chili is rich in vitamins A and C, niacin, riboflavin and thiamin, chili is used as a cooking spice and medicine. One of the obstacles to the low production of chili in Indonesia is caused by the attack of plant viruses, for that it is necessary to control the disease, one of which is using chitosan derived from gold snail shells. The aim of the study was to determine the ability of golden snail chitosan in controlling diseases caused by the chili pepper plant. This research was conducted at the plant experimental garden, Faculty of Agriculture, Jambi University. The study used a Randomized Block Design (RBD), which consisted of 7 treatments and 4 replications so that there were 28 experimental units, each experimental unit consisted of 12 treatments: P0: Control, P1: Seeds soaked in gold snail shell chitosan suspension, P2: Seeds soaked in industrial chitosan suspension, P3: Seedlings Chitosan sprayed with golden snail chitosan, P4: Seeds soaked and sprayed with golden snail chitosan, P5: Chili seeds sprayed with industrial chitosan, P6: Seeds soaked and sprayed with industrial chitosan. curly disease caused by $26.7 \%$ lower than control by $46.7 \%$. Seed treatment was soaked and sprayed with golden snail chitosan, the incidence of curly disease caused was $39.6 \%$ lower than the control at $58.3 \%$. The highest peroxidase enzyme activity was found in the treatment of seeds soaked in golden snail chitosan suspension of $1.58631 \mathrm{U} / \mathrm{g} / \mathrm{min}$ and the lowest was found in the control as much as $0.79649 \mathrm{U} / \mathrm{g} / \mathrm{min}$. The increase in peroxidase enzyme activity was $13.05-99.16 \%$. The vector insects found in this study were Bemisia tabaci and Aphis sp.
\end{abstract}

Keywords : Chitosan, golden snail shell, diseases caused by viruses.

\begin{abstract}
Abstrak.Cabai merupakan tanaman perdu dari Famili Solanaceae . Cabai kaya vitamin A dan C,niacin, riboflavin dan thiamin, cabai dimanfaatkan sebagai salah satu bumbu masak dan obat -obatan. salah satu kendala rendahnya produksi cabai di Indonesia disebabkan oleh serangan virus tanaman, untuk itu perlu dilakuakan pengendalian penyakit, salah satunya menggunakan kitosan yang berasal dari cangkang keong mas. Penelitian bertujuan untuk mengetahui kemampuan kitosan keong mas dalam mengendalikan penyakit yang disebabkan oleh virus pada tanaman cabai. Penelitian ini dilaksanakan di Kebun Percobaan Tanaman Fakultas Pertanian Universitas Jambi. Penelitian menggunakan Rancangan Acak Kelompok (RAK), yang terdiri dari 7 perlakuan dan 4 ulangan sehingga terdapat 28 satuan percobaan,setiap satuan percobaan terdiri dari 12 Perlakuan adalah:P0:Kontrol,P1: Benih direndam disuspensi kitosan cangkang keong mas, P2 : Benih direndam disuspensi kitosan industrial,P3:Bibit cabai disemprot dengan kitosan keong mas,P4:Benih direndam dan disemprot dengan kitosan keong mas , P5 : Bibit cabai disemprot dengan kitosan industrial,P6:Benih direndam dan disemprot dengan kitosan industrial.Berdasarkan hasil penelitian perlakuan kitosan benih direndam dan disemprot dengan kitosan industrial intensitas penyakit keriting yang ditimbulkan yaitu 26,7 \% lebih rendah dari pada kontrol sebesar 46,7 \%. Perlakuan benih direndam dan disemprot dengan kitosan keong mas kejadian penyakit keriting yang ditimbulkan yaitu39,6\% lebih rendah daripada kontrol sebesar 58,3\%. Aktivitas enzim peroksidase yang tertinggi terdapat pada perlakuan perlakuan benih direndam disuspensi kitosan keong mas sebesar1,58631U/g/min dan yang terendah terdapat pada kontrol sebanyak 0,79649 U/g/min peningkatan aktivitas enzim peroksidase adalah 13,05 - 99,16 \%. Serangga vektor yang ditemukan dalam penelitian ini adalah Bemisia tabaci dan Aphis sp.
\end{abstract}

Kata Kunci : Kitosan,cangkang keong mas,penyakit yang disebabkan virus.

\section{PENDAHULUAN}

Cabai adalah tanaman dalam dari Solanaceae. Beberapa jenis cabai yang dikenal adalah cabai besar (Capsicum annuum), C. frutescens, C. baccatum, C. pubescens dan C. chinense. Cabai rawit kaya akan vitamin A dan C, niasin, riboflavin dan tiamin (AVRDC 2003). Cabai (C.annuum) merupakan tanaman hortikultura yang banyak ditanam oleh petani Indonesia. Memang cabai memiliki nilai ekonomi yang relatif tinggi (Najah, 2016).

Produksi cabai merah di Jambi mengalami fluktuasi selama 5 tahun terakhir, pada tahun 2014 produksi cabai sebesar 36.715.000 ton, kemudian menurun pada tahun 2015 menjadi 30.341 .000 ton dan meningkat menjadi 39.523.000 ton pada tahun 2016, namun pada tahun 2017 dan 2018 terus menurun menjadi 31.572 ribu ton. Produksi cabai di Jambi pada tahun 2019 sebesar 42.698 ribu ton (Badan Pusat Statistik, 2019).

Salah satu kendala rendahnya hasil cabai di Indonesia disebabkan oleh virus tanaman. Pertumbuhan tanaman cabai yang terinfeksi virus umumnya terhambat dan hasil panen sangat berkurang (Monica, pinem dan Oemry 2017). Penyakit mosaik cabai merupakan salah satu penyakit utama yang disebabkan oleh virus dan dapat ditularkan dari tanaman yang sakit ke tanaman yang sehat melalui kutu daun (Gunaeni dan Wulandari, 2010).

Aktivitas virus yangi sangat tinggi diduga mempengaruhi metabolisme, sehingga dapat menurunkan metabolit primer dan pertumbuhan tanaman. Proses metabolism utama adalah fotosintesis yang 
melibatkan pigmen klorofil (Gonçalves, Vega, Oleivera dan Gomes. 2005).

Kitosan diyakini memiliki efek insektisida yang membunuh Aphis nerii pada oleander dan Spodoptera littoralis pada kapas di Mesir (Badawy dan ElAswad 2012). Aktivitas insektisida kitosan telah dilaporkan membunuh 70\%-99\% padi Rhopalosiphum (L.), kutu daun Metopolophium dirhodum (Walker), A. gossypii (Glover), Sitobion avenae (Fabricius) dan Myzus persicae ( Sulzer) menyerang tanaman. bunga Hyalopterus. prem (Goffroy) (Zhang, Tan, Yuan dan rui. 2003). Kitosan juga memiliki efek penghambatan pada makanan kutu dan aktivitas insektisida (Zhang et al. 2003), dan memiliki efek antibiotik dan antimikroba (Saguez, Hainez, Cherqui, Van, Jeanpierre, Lebon, Noiraud, Beaujean, Jouanin, Laberche dan Vincent. 2005).

\section{METODE PENELITIAN}

Penelitian ini dilaksanakan selama 6 bulan dari bulan Juli sampai bulan November 2020 bertempat di Kebun Percobaan Tanaman Universitas Jambi.

Bahan yang digunakan pada penelitian ini adalah cangkang keong mas, kitosan industrial (CV. Chimultiguna Bio Indonesia), Asam asetat, Natrium hidroksida (Merck), Asam klorida (Merck), pH, Aquades, Bufferfosfat, polybag, benih cabai keriting varietas Laris, pupuk kandang. Alat yang digunakan adalah labu ukur, gelas piala, label, gelas beker, cangkul, alat dokumentasi (handphone android), timbangan analitik, meteran, kain saring, plastik, gelas ukur dan pemanas.

Penelitian dilaksanakan dilapangan dengan menggunakan Rancangan Acak Kelompok (RAK), yang terdiri dari 7 perlakuan dan 4 ulangan sehingga terdapat 28 satuan percobaan, setiap satuan percobaan terdiri dari atas 12 tanaman sehingga terdapat 336 tanaman. Perlakuan adalah perendaman benih cabai dengan kitosan dan penyemprotan pada bibit umur 2 minggu dipersemain. Perlakuan adalah : P0: Kontrol (Tanpa Kitosan), P1: Benih direndam disuspensi kitosan cangkang keong mas, P2 : Benih direndam disuspensi kitosan industrial, P3 : Bibit cabai umur 2 minggu disemprot dengan kitosan keong mas, P4 : Benih direndam dan disemprot dengan kitosan keong mas pada umur 2 minggu, P5 : Bibit cabai umur 2 minggu disemprot dengan kitosan industrial, P6 : Benih direndam dan disemprot dengan kitosan industrial pada umur 2 minggu, Data hasil pengamatan dianalisis secara statistik dengan menggunakan analisis ragam, dilanjutkan dengan uji beda nila irata-rata menggunakan uji DNMRT (Duncan New Multiple RangeTest) pada taraf a 5\%.

Langkah pertama melakukan preparasi sampel meliputi pengambilan cangkang, pembersihan, menghaluskan, kemudian dipisahkan antara daging dan cangkang lalu dicuci sampai bersih, dikeringkan di bawah cahaya matahari selama 2 hari dan terakhir menghaluskancangkang dengan menggunakan penggilingan sampai halus lalu diayak, Metode yang digunakan dalam pembuatan kitosan adalah metode Hong (1989), dengan rangkaian pengerjaan deproteinase, demineralisasi, deasitilasi.

Benih cabai disemai pada polybag berisi media tanam steril berupa tanah lempung berpasir dan pupuk kandang 2:1 disemai 3 benih perpolibag, setelah bibit berumur 2 minggu dipilih satu bibit yang pertumbuhannya paling baik. Penyemprotan kitosan pada bibit cabai dilakukan pada umur 2 minggu.

Lahan sebagai tempat penelitian dibersihkan dari gulma, pengolahan tanah yang diterapkanadalah maximum tillage (olah tanah maksimal). Pengolahan tanah pertamai dilakukandengancara mencangkul tanah dengan kedalaman $20 \mathrm{~cm}$ namun masih berbentuk bongkahan, diikutipengolahan tanah keduayang bertujuan menghaluskan tanah. Kemudian dilanjutkan denganpembuatan petakan, Ukuran petak percobaan $80 \mathrm{~cm}$ x 2,5 m Jarak antar petakan $80 \mathrm{~cm}$ dan jarakantar ulangan $100 \mathrm{~cm}$. Pemberian pupuk kandang dengan dosis 5 ton/ha dan Setiappetakanterdiridari 12 tanaman dan dipasangmulsaplastik padasetiap bedengan.

Bibit cabai berumur 4 minggu dipindahkan kepertanaman cabai dengan jarak tanam $40 \mathrm{cmx} 30 \mathrm{~cm}$, Pemeliharaan meliputi penyiraman, pembersihan gulma dan pemasangan lanjaran padatanaman cabai. Penyiraman dilakukan pagi hari jika tidak hujan, pembersihan gulma dilakukan 2minggu sekali dan pemasang lanjaran dilakukan pada saat pemindahan cabai kelapangan. Tujuandaripemasangan lanjaranini supayatanamantidakrebah. Variabelpengamatan dalampenelitianini adalah:

\section{IntensitasPenyakitVirus}

Pengamatan intensitas penyakit dilakukan 4 kali pengamatan yaitu tanaman berumur 7, 14,21, dan 28 hari.Intensitas penyakit dihitungdengan rumus(Dolores,1996) :

$$
I=\frac{\sum\left(n_{i} \times v_{i}\right)}{N \times V} \times 100 \%
$$

Keterangan: $\quad \mathrm{I}=$ intensitas penyakit; $n i=$ jumlah tanaman yang termasuk kedalam skala ke $i$; $v i=$ nilai skoring gejala ke $-i ; N=$ jumlah tanaman yang diamati dan $V=$ nilai skoring tertinggi 
Doris Olviari Hamta, Asniwita, dan Novalina. Efektivitas Kitosan Cangkang Keong Mas Dalam Mengendalikan Penyakit Yang Disebakan Virus Pada Tanaman Cabai (Capsicumannuum L)

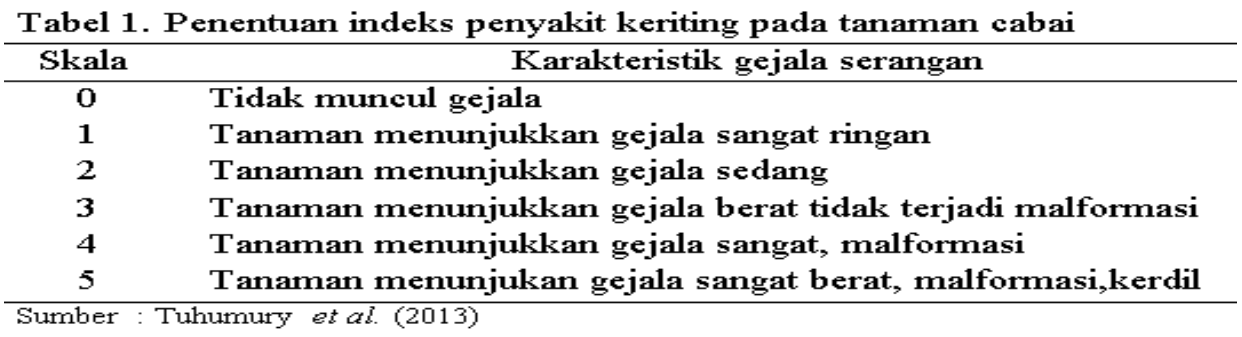

Tabel 2. Penentuan indeks penyakit mosaik pada tanaman cabai

\begin{tabular}{cl}
\hline Skala & \multicolumn{1}{c}{ Karakteristik gejala serangan } \\
\hline 0 & Tidak muncul gejala \\
1 & Tanaman menunjukkan gejala lesio lokal \\
2 & Tanaman menunjukkan gejala mosaik ringan \\
3 & Tanaman menunjukkan gejala mosaik berat \\
4 & Tanaman menunjukkan gejala mosaik, malformasi bentuk daun \\
5 & Gejala mosaik atau belang sangat berat dengan penciutan atau \\
& malformasi bentuk daun yang parah, kerdil. \\
Sumber : Dolores LM. (1996)
\end{tabular}

\section{Kejadiani Penyakit}

Pengamatan kejadian penyakit dilakukan terhadap jumlah tanaman yang menunjukkan gejala dan jumlah seluruh tanaman cabai yang ada disetiap lokasi pengamatan. Nilai kejadian penyakit dihitung menggunakan rumus (Natawigena, 1993):

$$
\mathrm{P}=\frac{n}{N} \times 100 \%
$$

Keterangan $: \mathrm{P}=$ persentase tanaman terinfeksi penyakit $\mathrm{n}=$ jumlah tanaman yang terinfeksi $\mathrm{N}=$ jumlah seluruh tanaman yang diamati

\section{PopulasiSeranggaVektor}

Populasi serangga vektor dihitung setelah pengamatan intesitas virus pada tanaman cabaihal ini dilakukan karena sifat virus mudah menular dengancara menghitung jumlah semuaseranggavektor pada tiap tanaman secara langsung.

\section{Aktivitas Enzim Peroksidase}

Analisis aktivitas enzim peroksidase dilakukan dengan metode Kardan Mishra (1976). Analisis dilakukan terhadap daun tanaman sampel yang digunakan 1 gram sampel dalam keadaan segar.

\section{HASIL DAN PEMBAHASAN}

Hasil penelitian menunjukkan bahwa ada dua jenis penyakit yang disebabkan oleh virus: rambut keriting dan penyakit mosaik. Gejala mosaik dan penyakit virus Keriting tidak ditemukan pada pengamatan 7 hst (hari setelah tanam), dan gejala baru muncul pada pengamatan 14 hst. Gejala penyakit keriting pada tanaman cabai dimulai dengan pucuk, daun, urat menjadi bening dan kuning bening, urat menebal, daun mengering dan daun berkontraksi bila terjadi infeksi tambahan. Kemudian tanaman stagnasi menunjukkan gejala kuning cerah (Gbr. 4). ), Dalam penelitian ini, gejala penyakit mosaik cabai (Gambar 5) adalah lesi lokal, fenomena mosaik ringan, fenomena mosaik serius, deformasi daun dan tanaman kerdil. 


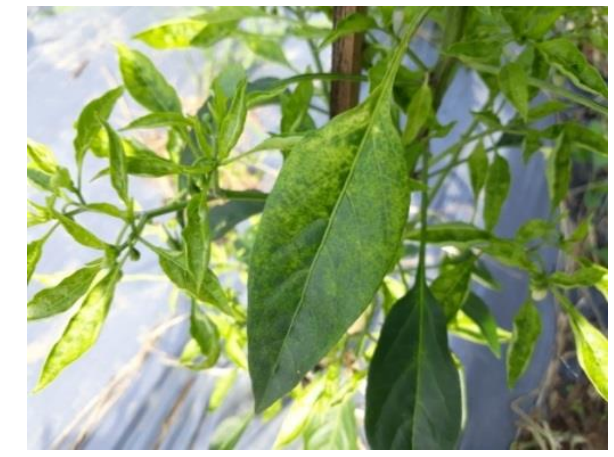

Gambar 1. Penyakit keriting

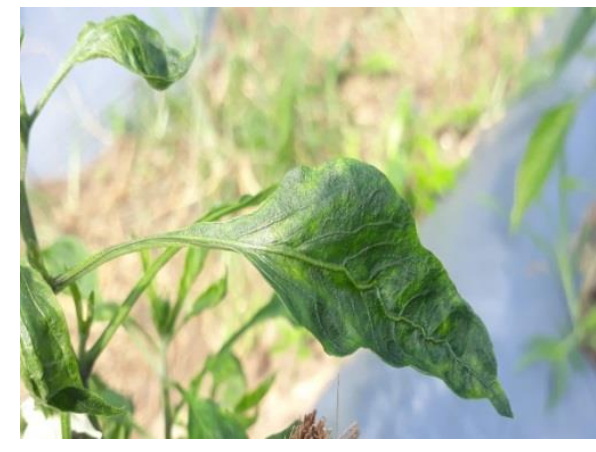

Gambar 2. Penyakit mosaik

\section{Penyakit keriting pada cabai}

\section{Intensitas penyakit keriting pada cabai}

Hasil analisis ragam menunjukan bahwa pemberian perlakuan kitosan berpengaruh nyata terhadap intensitas penyakit keriting pada tanaman cabai pada pengamatan 14, 21 dan 28 hst nilai rata - rata intensitas penyakit keriting pada masing-masing perlakuan disajikan pada Tabel 3. Perlakuan pemberian kitosan tidak berbeda nyata antar satu dan lain nya tetapi berbeda nyata dengan kontrol ( tanpa kitosan keong mas dan industri). Perlakuan tanpa kitosan keong mas dan industri menunjukkan intensitas penyakit tertinggi yaitu 46,3\% (Tabel 3) dan yang terendah pada perlakuan benih direndam dan disemprot dengan kitosan industrial yaitu sebesar 26,7\%. Pada pengamatan,i14, 21 dan 28 hari setelah tanam menunjukan terjadinya peningkatan intensitas penyakit keriting.

Tabel 3. Intensitas penyakit keriting pada tanaman cabai dengan pemberian kitosan cangkang keong mas dan industri.

\begin{tabular}{|c|c|c|c|c|}
\hline \multirow{2}{*}{ Perlakuan } & \multicolumn{4}{|c|}{ Intensitas penyakit keriting (\%) } \\
\hline & $7 \mathrm{hst}$ & 14 hst & 21 hst & $28 \mathrm{hst}$ \\
\hline Kontrol (tanpa kitosan keong mas dan industri) & - & 19,6 a & $31,7 \mathrm{a}$ & $46,3 \mathrm{a}$ \\
\hline $\begin{array}{l}\text { Benih direndam disuspensi kitosan cangkang } \\
\text { keong mas }\end{array}$ & - & $12,9 \mathrm{~b}$ & $22,1 \mathrm{~b}$ & $33,3 \mathrm{~b}$ \\
\hline Benih direndam disuspensi kitosan industrial & - & $14,2 \mathrm{~b}$ & $17,9 \mathrm{~b}$ & $34,2 \mathrm{~b}$ \\
\hline $\begin{array}{l}\text { Bibit cabai disemprot dengan kitosan keong } \\
\text { mas }\end{array}$ & - & $12,5 \mathrm{~b}$ & $17,9 \mathrm{~b}$ & $30,4 \mathrm{~b}$ \\
\hline $\begin{array}{l}\text { Benih direndam dan disemprot dengan kitosan } \\
\text { keong mas }\end{array}$ & - & $10,0 \mathrm{~b}$ & $18,3 \mathrm{~b}$ & $29,6 \mathrm{~b}$ \\
\hline Bibit cabai disemprot dengan kitosan industrial & - & $10,0 \mathrm{~b}$ & $16,3 \mathrm{~b}$ & $30,0 \mathrm{~b}$ \\
\hline $\begin{array}{l}\text { Benih direndam dan disemprot dengan kitosa } \\
\text { industrial }\end{array}$ & - & $9,6 \mathrm{~b}$ & $18,3 \mathrm{~b}$ & $26,7 \mathrm{~b}$ \\
\hline
\end{tabular}

Keterangan:Angka pada tiap kolom yang sama diikuti dengan huruf sama tidak berbeda nyata menurut uji DNMRT pada taraf $5 \%$

- = tidak muncul gejala penyakit

hst : hari setelah tanam

\section{Kejadian penyakit keriting pada cabai}

Hasil analisis ragam menunjukan bahwa pemberian kitosan berpengaruh nyata terhadap kejadian penyakit keriting pada tanaman cabai pada pengamatan 14, 21 dan 28 hst. Nilai rata - rata kejadian penyakit keriting pada masing-masing perlakuan disajikan pada Tabel 4. Hasil pengamatan kejadian penyakit keriting pada tanaman cabai perlakuan tanpa kitosan keong mas dan industri menunjukkan kejadian penyakit tertinggi yaitu 58,3\%, sedangkan yang terendah pada perlakuan benih direndam dengan kitosan keong mas dan disemprot dengan kitosan keong mas pada umur 2 minggu menunjukkan kejadian penyakit sebesar 39,6\%. Pengamatan pada 14, 21 dan 28 hari setelah tanam menunjukan terjadinya peningkatan kejadian penyakit keriting. 
Doris Olviari Hamta, Asniwita, dan Novalina. Efektivitas Kitosan Cangkang Keong Mas Dalam Mengendalikan Penyakit Yang Disebakan Virus Pada Tanaman Cabai (Capsicumannuum L)

Tabel 4. Kejadian penyakit keriting pada tanaman cabai dengan pemberian kitosan kitosan cangkang keong mas dan industri.

\begin{tabular}{|c|c|c|c|c|}
\hline \multirow{2}{*}{ Perlakuan } & \multicolumn{4}{|c|}{ Kejadian penyakit keriting (\%) } \\
\hline & 7 hst & 14 hst & 21 hst & $28 \mathrm{hst}$ \\
\hline $\begin{array}{l}\text { Kontrol (tanpa kitosan keong mas dan } \\
\text { industri) }\end{array}$ & - & $52,1 \mathrm{a}$ & $52,1 \mathrm{a}$ & $58,3 \mathrm{a}$ \\
\hline $\begin{array}{l}\text { Benih direndam disuspensi kitosan cangkang } \\
\text { keong mas }\end{array}$ & - & $37,5 \mathrm{~b}$ & $37,5 \mathrm{~b}$ & $41,7 \mathrm{~b}$ \\
\hline Benih direndam disuspensi kitosan industrial & - & $31,3 \mathrm{~b}$ & $39,6 \mathrm{ab}$ & $45,8 \mathrm{~b}$ \\
\hline $\begin{array}{l}\text { Bibit cabai disemprot dengan kitosan keong } \\
\text { mas }\end{array}$ & - & $31,3 \mathrm{~b}$ & $33,3 \mathrm{~b}$ & $43,8 \mathrm{~b}$ \\
\hline $\begin{array}{l}\text { Benih direndam dan disemprot dengan } \\
\text { kitosan keong mas }\end{array}$ & - & $27,1 \mathrm{~b}$ & $33,3 \mathrm{~b}$ & $39,6 \mathrm{~b}$ \\
\hline $\begin{array}{l}\text { Bibit cabai disemprot dengan kitosan } \\
\text { industrial }\end{array}$ & - & $27,1 \mathrm{~b}$ & $27,1 \mathrm{~b}$ & $41,7 \mathrm{~b}$ \\
\hline $\begin{array}{l}\text { Benih direndam dan disemprot dengan kitosa } \\
\text { industrial }\end{array}$ & - & $27,1 \mathrm{~b}$ & $31,3 \mathrm{~b}$ & $41,7 \mathrm{~b}$ \\
\hline
\end{tabular}

\section{Penyakit mosaik pada cabai \\ Intensitas penyakit mosaik pada cabai}

Hasil analisis ragam menunjukan bahwa pemberian kitosan berpengaruh nyata terhadap intensitas penyakit mosaik pada tanaman cabai pada pengamatan 14, 21 dan 28 hst. Nilai rata - rata intensitas penyakit mosaik pada masing-masing perlakuan disajikan pada Tabel 5. Intensitas penyakit mosaik tertinggi terdapat pada perlakuan bibit cabai umur 2 minggu disemprot dengan kitosan industrial sebesar 36,7\% sedangkan yang terendah pada perlakuan bibit cabai umur 2 minggu disemprot dengan kitosan keong mas sebesar 22,1\%. Intensitas penyakit mosaik pada pengamatan 14, 21 sampai 28 hari setelah tanam menunjukan peningkatan intensitas penyakit mosaik.

Tabel 5. Intensitas penyakit mosaik pada tanaman cabai dengan pemberian kitosan cangkang keong mas dan industri.

\begin{tabular}{lllll}
\hline \multicolumn{1}{c}{ Perlakuan } & \multicolumn{4}{c}{ Intensitas penyakit mosaik (\%) } \\
\cline { 2 - 5 } & $7 \mathrm{hst}$ & $14 \mathrm{hst}$ & $21 \mathrm{hst}$ & $28 \mathrm{hst}$ \\
\hline $\begin{array}{l}\text { Kontrol (tanpa kitosan keong mas dan } \\
\text { industri) }\end{array}$ & - & $13,8 \mathrm{ab}$ & $24,6 \mathrm{a}$ & $31,3 \mathrm{ab}$ \\
$\begin{array}{l}\text { Benih direndam disuspensi kitosan } \\
\text { cangkang keong mas }\end{array}$ & - & $15,4 \mathrm{a}$ & $25,4 \mathrm{a}$ & $32,1 \mathrm{ab}$ \\
$\begin{array}{l}\text { Benih direndam disuspensi kitosan } \\
\text { industrial }\end{array}$ & - & $17,1 \mathrm{a}$ & $27,1 \mathrm{a}$ & $33,8 \mathrm{a}$ \\
$\begin{array}{l}\text { Bibit cabai disemprot dengan kitosan } \\
\text { keong mas }\end{array}$ & - & $10,0 \mathrm{~b}$ & $15,4 \mathrm{~b}$ & $22,1 \mathrm{~b}$ \\
$\begin{array}{l}\text { Benih direndam dan disemprot dengan } \\
\text { kitosan keong mas }\end{array}$ & - & $13,8 \mathrm{ab}$ & $23,8 \mathrm{a}$ & $30,0 \mathrm{ab}$ \\
$\begin{array}{l}\text { Bibit cabai disemprot dengan kitosan } \\
\text { industrial }\end{array}$ & - & $16,3 \mathrm{a}$ & $26,3 \mathrm{a}$ & $36,7 \mathrm{a}$ \\
$\begin{array}{l}\text { Benih direndam dan disemprot dengan } \\
\text { kitosa industrial }\end{array}$ & - & $13,3 \mathrm{ab}$ & $22,1 \mathrm{a}$ & $30,8 \mathrm{ab}$ \\
\hline
\end{tabular}

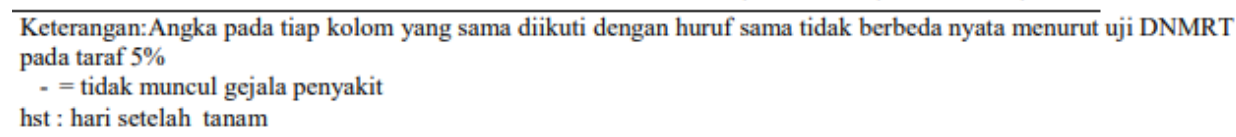

\section{Kejadian penyakit mosaik pada cabai}

Hasil analisis ragam menunjukan bahwa pemberian kitosan berpengaruh nyata terhadap kejadian penyakit mosaik pada tanaman cabai pada pengamatan 14, 21 dan 28 hst (hari setelah tanam). Nilai rata - rata intensitas penyakit keriting pada masing- masing perlakuan disajikan pada Tabel 6. Kejadian penyakit mosaik pada perlakuan bibit cabai umur 2 minggu disemprot dengan kitosan industrial menunjukkan kejadian penyakit yang tertinggi sebesar 43,8\% dan yang terendah pada perlakuan bibit cabai umur 2 minggu disemprot dengan kitosan keong mas sebesar $27,1 \%$. Pengamatan pada 14, 21 sampai 28 hari setelah tanam menunjukan peningkatan kejadian penyakit mosaik. 
Doris Olviari Hamta, Asniwita, dan Novalina. Efektivitas Kitosan Cangkang Keong Mas Dalam Mengendalikan Penyakit Yang Disebakan Virus Pada Tanaman Cabai (Capsicumannuum L)

Tabel 6. Kejadian mosaik pada tanaman cabai dengan pemberian kitosan cangkang keong mas dan industri.

\begin{tabular}{|c|c|c|c|c|}
\hline \multirow{2}{*}{ Perlakuan } & \multicolumn{4}{|c|}{ Kejadian penyakit mosaik ((\%) } \\
\hline & $7 \mathrm{hst}$ & 14 hst & 21 hst & 28 hst \\
\hline $\begin{array}{l}\text { Kontrol (tanpa kitosan keong mas dan } \\
\text { industri) } \\
\text { Benih direndam disusnensi kitosan canokang }\end{array}$ & - & $35,4 \mathrm{~b}$ & $37,5 \mathrm{ab}$ & $37,5 \mathrm{ab}$ \\
\hline $\begin{array}{l}\text { Benih direndam disuspensi kitosan cangkang } \\
\text { keong mas }\end{array}$ & - & $39,6 \mathrm{~b}$ & $41,7 \mathrm{a}$ & $41,7 \mathrm{a}$ \\
\hline Benih direndam disuspensi kitosan industrial & - & $39,6 \mathrm{~b}$ & $43,8 \mathrm{a}$ & $43,8 \mathrm{a}$ \\
\hline $\begin{array}{l}\text { Bibit cabai disemprot dengan kitosan keong } \\
\text { mas }\end{array}$ & - & $25,0 \mathrm{~b}$ & $27,1 \mathrm{~b}$ & $27,1 \mathrm{~b}$ \\
\hline $\begin{array}{l}\text { Benih direndam dan disemprot dengan } \\
\text { kitosan keong mas }\end{array}$ & - & $35,4 \mathrm{~b}$ & $37,5 \mathrm{ab}$ & 39,6 a \\
\hline $\begin{array}{l}\text { Bibit cabai disemprot dengan kitosan } \\
\text { industrial }\end{array}$ & - & 43,8 a & $43,8 \mathrm{a}$ & 43,8 a \\
\hline $\begin{array}{l}\text { Benih direndam dan disemprot dengan kitosa } \\
\text { industrial }\end{array}$ & - & $35,4 \mathrm{~b}$ & $35,4 \mathrm{ab}$ & $37,5 \mathrm{ab}$ \\
\hline
\end{tabular}

\section{Serangga vektor}

Hasil pengamatan pada penelitian menemukan 2 jenis serangga vektor yaitu kutu putih dan Aphids, Kutu putih (B. tabaci) ada disetiap perlakuan sedangkan Aphis sp. hanya terdapat pada perlakuan tanpa kitosan keong mas dan industri, Benih direndam disuspensi kitosan cangkang keong mas, bibit cabai umur 2 minggu disemprot dengan kitosan keong mas, dan Bibit cabai umur 2 minggu disemprot dengan kitosan industrial .

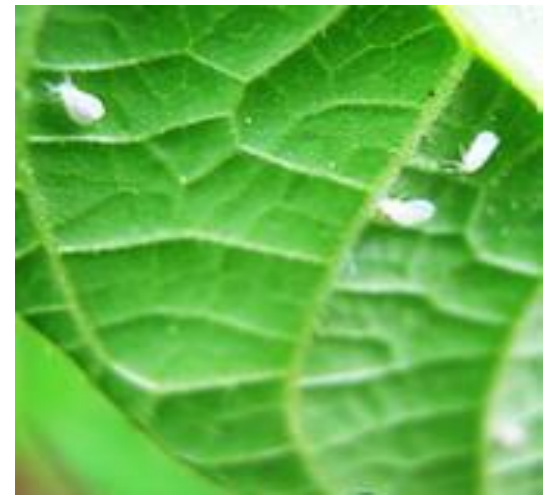

Gambar 3. Bemisia tabaci

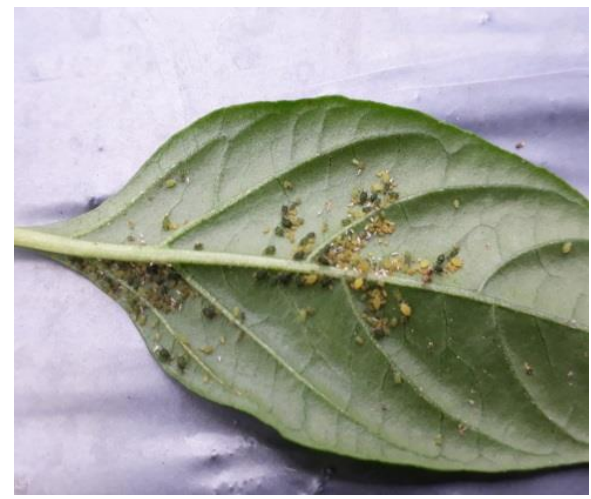

Gambar 4.Aphis sp.

Tabel 8. Pengamatan serangga vektor dengan pemberian kitosan cangkang keong mas dan industri.

\begin{tabular}{lcc}
\hline \multirow{2}{*}{ Perlakuan } & \multicolumn{2}{c}{ Serangga vektor } \\
\cline { 2 - 3 } & $\begin{array}{c}\text { Bemisia } \\
\text { tabaci }\end{array}$ & $\begin{array}{c}\text { Aphis } \\
\text { sp. }\end{array}$ \\
\hline Kontrol (tanpa kitosan keong mas dan industri) & 15 & 202 \\
Benih direndam disuspensi kitosan cangkang keong & 13 & 46 \\
mas & 18 & 0 \\
Benih direndam disuspensi kitosan industrial & 14 & 58 \\
Bibit cabai disemprot dengan kitosan keong mas & 12 & 0 \\
Benih direndam dan disemprot dengan kitosan keong & 10 & 12 \\
mas & 17 & 0 \\
Bibit cabai disemprot dengan kitosan industrial & & \\
Benih direndam dan disemprot dengan kitosa industrial & & \\
\hline
\end{tabular}

\section{Aktivitas Enzim peroksidase}

Hasil aktivitas enzim peroksidase pada tanaman cabai menunjukkan aktivitas tertinggi terdapat pada perlakuan benih direndam disuspensi kitosan cangkang keong mas dan yang terendah pada perlakuan tanpa kitosan keong mas dan industri Tabel 9. Aktivitas enzim peroksidase perlakuan dengan kitosan cangkang keong mas lebih tinggi dari 
Doris Olviari Hamta, Asniwita, dan Novalina. Efektivitas Kitosan Cangkang Keong Mas Dalam Mengendalikan Penyakit Yang Disebakan Virus Pada Tanaman Cabai (Capsicumannuum L)

perlakuan yang diberi kitosan industri.

Tabel 9. Aktivitas enzim peroksidase dengan pemberian kitosan cangkang keong mas dan industri.

\begin{tabular}{lcc}
\hline \multicolumn{1}{c}{ Perlakuan } & $\begin{array}{c}\text { Aktivitas Enzim } \\
\text { peroksidase } \\
(\mathrm{U} / \mathrm{g} / \mathrm{min})\end{array}$ & $\begin{array}{c}\text { Peningkatan Enzim } \\
\text { peroksidase ( \%) }\end{array}$ \\
\hline $\begin{array}{l}\text { Kontrol (tanpa kitosan keong mas } \\
\text { dan industri) }\end{array}$ & 0,79649 & $00.00 \%$ \\
$\begin{array}{l}\text { Benih direndam disuspensi kitosan } \\
\text { cangkang keong mas }\end{array}$ & 1,25514 & $57,58 \%$ \\
$\begin{array}{l}\text { Benih direndam disuspensi kitosan } \\
\text { industrial }\end{array}$ & 1,03074 & $29,41 \%$ \\
$\begin{array}{l}\text { Bibit cabai disemprot dengan kitosan } \\
\text { keong mas }\end{array}$ & 1,58631 & $99,16 \%$ \\
$\begin{array}{l}\text { Benih direndam dan disemprot } \\
\text { dengan kitosan keong mas }\end{array}$ & 1,16509 & $46,28 \%$ \\
$\begin{array}{l}\text { Bibit cabai disemprot dengan kitosan } \\
\text { industrial }\end{array}$ & 0,90043 & $13,05 \%$ \\
$\begin{array}{l}\text { Benih direndam dan disemprot } \\
\text { dengan kitosa industrial }\end{array}$ & 0,97643 & $22,59 \%$ \\
\hline
\end{tabular}

Berdasarkan penelitian ditemukan 2 jenis penyakit yang disebabkan oleh virus yaitu penyakit keriting dan mosaik. Gejala penyakit virus mulai ditemukan pada pengamatan 14 Hst. Gejala penyakit keriting yang ditemukan pada penelitian adalah daun -daun muda yang terserang mengalami vein clearing, menguning dan berkembang menjadi warna kuning (Gambar 3) sama yang dideskripsikan oleh Barrow, Hidayat, Frohlich dan Subandiyah (2008) gejala penyakit keriting pada tanaman cabai terserang mengalami vein clearing dimulai dari daun- daun pucuk berkembang menjadi warna kuning jelas, tulang daun menebal dan daun menggulung keatas.

Gejala penyakit mosaik pada pengamatan pada tanaman yang terinfeksi penyakit mosaik memperlihatkan gejala mosaik yang muncul berupa klorosis dengan perubahan warna daunmenjadi belang hijau kekuningan dengan tingkat keparahan yang berbeda. Taufik (2013) melaporkan tanaman yang terinfeksi oleh penyakit mosak berupa gejala lokal kemudian menyebar menjadi gejala sistemik, yakni munculnya mosaik yang diikuti dengan klorosis kemudian menyebar keseluruhan bagian tanaman dan serangan lebih lanjut menyebabkan malformasi.

Hasil penelitian menunjukkan bahwa perlakuan kitosan pada tanaman cabai menunjukkan intensitas dan kejadian penyakit keriting lebih rendah dibandingkan perlakuan tanpa kitosan keong mas dan industri, Hal ini membuktikan bahwa kitosan mampu menghambat intensitas penyakit keriting pada tanaman cabai. Liy, Yin, Wang, Zhao, DU, dan Li (2009) menyatakan bahwa kitosan dapat meningkatkan ketahanan tanaman terhadap stres dengan menginduksi produksi nitrit oksida dan hydrogen peroksida. Kitosan juga dapat menonaktifkan sintesis mRNA yang dikodekan

oleh gen untuk metabolik dan infeksi dari virus atau viroid (Kulikov, Chirkov, Ilina, Lopatin dan Varlamov .,2006 ). Penelitian Nur s IY, (2019) menyatakan bahwa intesitas penyakit TMV dengan menggunakan kitosan industri sebesar 41,67 \% sedangkan pada perlakuan kontrol sebesar 63,89\%. Tanaman yang disemprot dengan kitosan kejadian penyakit yang sebabkan oleh BCMV lebih rendah dibandingkan dengan tanaman kontrol tanpa perlakuan kitosan (Megasari, Damayanti dan Santoso 2014).

Berdasarkan hasil penelitian bahwa perlakuan bibit cabai disemprot dengan kitosan keong mas intesitas dan kejadian penyakit mosaik lebih rendah dari perlakuan kontrol tanpa kitosan keong mas dan industri dan perlakuan kitosan lain nya, bahkan ada perlakuan kitosan yang lebih tinggi dari pada kontrol. Kulikov et a,l menyatakan bahwa aktivitas langsung kitosan terhadap virus telah terbukti bervariasi sesuai dengan berat molekul, Namun tidak ada penelitian yang menyelidiki efek ini yang secara jelas membuktikan kemampuan kitosan dalam menonaktifkan virus secara sempurna. Tanaman yang terserang virus dalam menghasilkan klorofil a dan $b$ serta karotenoid akan mengalami penurunan dan tidak dapat menghasilkan senyawa fosofrilase yang memiliki peran sebagai senyawa untuk pertumbuhan dan juga perkembangan dari tanaman. Senyawa tersebut antara lain asam organik, asam amino, gula serta protein. Penurunan dari senyawa tersebut dapat menyebabkan gejala muncul dan intensitas dari penyakit akan semakin tinggi (Hidema, Makino, Kurita, Mae dan Ohjima 1992).

Kitosan merupakan senyawa kimia yang dapat membantu untuk mengaktifkan sistem pertahanan tanaman yang selanjutnya menginduksi pertahanan yang terdiri dari protein defensif atau pathogenesis related (PR). Protein tersebut dapat melindungi tanaman dari serangan patogen. PR protein mempunyai peran untuk mencegah multiplikasi, penyebaran serta lokalisasi virus pada jaringan tanaman yang terserang. PR protein ini akan terakumulasi pada bagian jaringan yang terinfeksi (Naylor, Murphy, Berry dan Carr 1998). Hal ini menunjukkan bahwa kitosan mampu menghambat penyebaran virus secara sistemik pada tanaman. Proses penyebaran dan replikasi 
dari virus mampu dihambat baik dengan pemberian kitosan sehingga perlakuan dengan kitosan dapat menyebabkan infeksi sistemik dari virus tidak dapat berkembang (Chirkov, 2002,).

Serangga vektor adalah faktor yang berperan sangat penting dalam penyakit yang disebabkan oleh virus pada tanaman cabai pada pengamatan penelitian ditemukan 2 jenis serangga vektor yang berada pada tanaman cabai yaitu kutu kebul Bemisia tabaci dan Aphis sp. Serangga ini termasuk dalam kelompok serangga penusuk penghisap. Serangga vektor dan hubungannya dengan penyakit yang disebabkan oleh virus cabai ini bersifat nonpersisten.

Kutu putih (B. tabaci) adalah merupakan vektor geminivirus yang memiliki daerah penyebaran yang luas terutama di daerah tropik dan sub tropik. Hasil penelitian yang dilakukan oleh Nur Aeni (2007). Aktivitas kutu kebul baru meningkat setelah tanaman mulai berbunga hingga awal pengisian buah. Peranan serangga vektor B. tabaci sangat penting dalam menularkan virus pada tanaman cabai (Trisno, SriIshak 2010). Duriat (2009) melaporkan bahwa pada percobaan dengan menggunakan satu imago B.tabaci dapat menularkan geminivirus dan menyebabkan tanaman cabai kecil menjadi sakit. Yuliani dan Dewi (2015) juga menyatakan virus yang ditularkan oleh kutu kebul (kutu putih) diantaranya adalah kelompok geminivirus yang dapat menyerang tanaman cabai.

Aktivitas kutu kebul baru meningkat setelah tanaman mulai berbunga hingga awal pengisian buah. Peranan serangga vektor $B$. tabaci sangat penting dalam menularkan virus pada tanaman cabai (Trisno et al. 2010). Pada penelitian ini jumlah A.gossypii banyak ditemukan pada perlakuan kontrol tanpa kitosan keong mas dan industri dibandingkan dengan tanaman perlakuan kitosan (Tabel 8). Hal ini menunjukkan bahwa kitosan memiliki efek antixenosis sehinggai secara nyata mempengaruhi preferensi makan A. gossypii. Kitosan menstimulasi tanaman untuk memproduksi antibodi sistemik dengan menghasilkan efek repelen yang menghalangi serangga untuk makan (Zeng, Luo, Tu 2012).

Berdasarkan hasil penelitian Aktivitas enzim peroksidase pada tanaman kontrol yaitu sebesar 0,79649 $\mathrm{U} / \mathrm{g} / \mathrm{min}$ (Tabel 9) protein. Adanya aktivitas enzim peroksidase pada tanaman yang tidak diberi perlakuan menunjukkan bahwa enzim peroksidase secara alami terdapat pada. Siegel ( 1993 ) menyatakan bahwa enzim peroksidase banyaki erdistribusi dialami dan dapat ditemukan pada tanaman, hewan dan mikroorganisme. Enzim peroksidase pada tanaman cabai selain berfungsi dalam sistem pertahanan tanaman, juga dapat berfungsi sebagai katalisator reaksi oksidatif capsaicin didalam menghasilkan capsaicin (Diaz, Pomar, Bernali dan Merino 2004).

Enzim peroksidase adalah indikatoriterjadinya induksi resistensi secara local maupun sistemik (El-Mougy, Abdel, Lashim dan Megahed 2013). Fungsi enzim peroksidase dalam sistem pertahanan tanaman diantaranya adalah memperkuat dinding sel melalui pembentukan protein struktural pada dinding sel tanaman dan biosintesis lignin (Stermer,1995). Menurut Vidhyasekaran(2004) enzim peroksidase berperan sebagai katalis dalam polimerasi monolignol untuk membentuk dinding sel tanaman. Selain itu enzim peroksidase dapat berfungsi sebagai katalis reaksi oksidasi senyawa fenolik menjadi senyawa kuinon dan menghasilkan $\mathrm{H} 2 \mathrm{O} 2$ yang toksik bagi pathogen (Turk1993) Bell (1988) menyatakan bahwa enzim peroksidase juga dapat mengkatalisas pembentukan senyawasenyawa metabolit sekunder yang bersifat toksik sebagai reaksi adanya serangan patogen .

Berdasarkan hasil penelitian aktivitas enzim peroksidase terhadapap tanaman yang diberi perlakakuan kitosan lebih tinggi dibandingkan dengan tanaman kontrol dan juga persentasepeningkatan aktifitas enzim peroksidase terlihat bahwa tanaman cabai yang diberi perlakuan dengan kitosan lebih tinggi 13,05 - 99,16\% dibandingkan dengan kontrol. Hal ini menunjukkan bahwa induksi ketahanan yang ditunjukkan oleh kitosan mampu meningkatan aktivitas enzim peroksidase. Van Loon, Pierpoint, Boller dan Conejero (1994) menyatakan bahwa peroksidase merupakan suatu kelompok PR protein (Pathogenesisi Related protein) dari golongan PR-9 yang terakumulasi pada saat tanaman sakit atau sejenisnya .

Menurut Zhou, Liu, Chen, Yu, Yang, dan Wang (1992) peningktan aktifitas enzim peroksidase diakibatkan tanaman terinfeksi virus yang akan berkorelasi dengan tingkat ketahanan terhadap virus. Senyawa kitosan yang masuk melalui stomata merupakan penentu mekanisme pertahanan tanaman terhadap virus. Souza, Oliveira, Peresi, Oliveriai dan Purcinoi (2003) menyatakan bahwa aktivitas enzimperoksidase merupakan indikator respons pertahanan tanaman terhadap infeksi virus. Kitosan menginduksi ketahanan tanaman terhadap virus melalui aposisi kalose (callose apposition) dan meningkatkan produksi etilen (Iriti, Castorina, Vitalini, Mignani, Soave, Fico dan Faoro 2010 ). 


\section{KESIMPULAN}

Berdasarkan penelitian yang telah dilakukan diperoleh kesimpulan yaitu:

1. Perlakuan benih direndam dan disemprot dengan kitosan industrial menunjukkann intensitas penyakit keriting yang ditimbulkan yaitu 26,7 \% lebih rendah dari pada kontrol sebesar 46,7 \%. Perlakuan bibit cabai disemprot dengan kitosan keong mas menunjukkann intensitas penyakit mosaik sebesaar 22,1\% lebih rendah dari perlakuan kontrol dan perlakuan kitosan lainnya.

2. Perlakuan benih direndam dan disemprot dengan kitosan keong mas kejadian penyakitkeriting yang ditimbulkan yaitu 39,6 \% lebih rendah dari pada kontrol sebesar 58,3\%. Perlakuan bibit cabai disemprot dengan kitosan keong mas menunjukkann kejadian penyakit mosaik sebesaar 27,1 \% lebih rendah dari perlakuan kontrol dan perlakuan kitosan lainnya.

3. Aktivitas enzim peroksidase yang tertinggi terdapat pada perlakuan perlakuan benih direndam disuspensi kitosan keong mas sebesar $1,58631 \mathrm{U} / \mathrm{g} / \mathrm{min}$ dan yang terendah terdapatpada kontrol sebanyak $0,79649 \mathrm{U} / \mathrm{g} / \mathrm{min}$ peningkatan aktivitas enzim peroksidase adalah 13,05-99,16\%.

Serangga vektor yang ditemukan penelitian ini adalah Bemisia tabaci dan Aphis sp.

\section{DAFTAR PUSTAKA}

AVRDC. 2003. Evaluation of phenotypic and molecular criteria for the identification for Colletotrichum species causing Pepper Antrachnose in Taiwan, p. 58-59.

Badan Pusat Statistik. 2019. Produksi cabai besar, cabai rawit, dan bawang merah. Statistik Indonesia. Jakarta.

Badawy MEI, El-Aswad A. 2012.Insecticidal activity of chitosans of different molecular weights and chitosan-metal complexes against cotton leafworm Spodoptera littoralis and oleander aphid Aphis nerii. Plant Protection Science 48:131-141.

Bell AA. 1988. Biochemical mechanisms of diseases resistance.Annual Review Plant Physiology. 32: 21-28.

Chirkov SN. 2002. The antiviral activity of chitosan (review). Applied Biochemistry and Microbiology. 38:1-8.

De Barrow P J, Hidayat SH, Frohlich D, Subandiyah D \& Shigenori U. 2008. A virus and its vector, Pepper Yellow Leaf Curl Virus and Bemisia tabaci, two new Invaders of indonesia. Biological Invasions 10 (4): 411-433.

Diaz J, Pomar F, Bernali A \& Merino F. 2004. Peroxidases and metabolism of capsaicin in Capsicum anuum L. Phytochemistry Reviews. 3: 141-157.

Dolores LM. 1996. Management of pepper viruses. Proceeding of the AVNET II Midterm Workshop AVRDC, ADB and PCARRD.

Duriat AS. 2009. Pengendalian penyakit kuning keriting pada tanaman cabai kecil. Balai Penelitian Tanaman Sayuran. Bandung.

El-Mougy NS, Abdel-Kader MM, Lashin SM \& Megahed AA. 2013. Fungicides alternativesias plant resistance inducers against foliar diseases incidenceiof some vegetables grown under plastic houses conditions. International Journal of Engineering and Innovative Technology (IJEIT). 3:71-81.

Gonçalves MC, Vega J, Oliveira JG \& Gomes MMA. 2005, Sugarcane yellow leaf virus infection leadsito alterations in photosynthetic efficiency and carbohydrate accumulation in sugarcane leaves, Fitopatol. Bras. 30(1):1-15.

Gunaeni N, \& Wulandari AW. 2010. Cara Pengendalian nonkimiawi terhadap serangga vektor kutu daun dan intensitas serangan penyakit virus mosaik pada tanaman cabai merah. Jurnal Hortikultura, 20(204):368376.

Hidema J, Makino A, Kurita Y, Mae T \& Ohjima K. 1992. Changes in the level of chlorophyll and light-harvesting chlorophyll $\mathrm{a} / \mathrm{b}$ protein PS II in rice leaves agent under different irradiances from full expansion through senescense, Plant Cell Physiol 33(8):1209-1214

Iriti M, Castorina G, Vitalini S, Mignani I, Soave C, Fico G \& Faoro F. 2010. Chitosan induced ethylenein dependent resistance does not reduce crop yield in bean. BioControl, 54: 241-247.

Kar M \& Mishra D. 1976. Catalase peroxidase and polyphenol oxidase activities during rice leaf senescence. Plant Physiol. 57:315-319

Kulikov SN, Chirkov SN, Ilina AV, Lopatin SA \& Varlamov VP. 2006. Effect of the molecular weight of chitosan on its antiviral activity in plants. Applied-Biochemistry and Microbiology.42(2):224-228.

Li Y, Yin H, Wang Q, Zhao X, DU Y, \& Li F. 2009. Oligochitosan induced Brassica napus L production of NO and $\mathrm{H} 2 \mathrm{O} 2$ and theiriph siological function. Carbohydrate Polymers 75(4): 612- 617.

Megasari D, Damayanti TA, Santoso S. 2015. Pengendalian Aphis cracccivora Koch. dengan kitosan dan pengaruhnya terhadap penularan Bean common mosaic virus strain Black eye cowpea (BCMV-BIC) pada kacang panjang. Jurnal Entomologi Indonesia.11:72-80. 
Doris Olviari Hamta, Asniwita, dan Novalina. Efektivitas Kitosan Cangkang Keong Mas Dalam Mengendalikan Penyakit Yang Disebakan Virus Pada Tanaman Cabai (Capsicumannuum L)

Monica S , Pinem M \& Oemry S.2017. Hubungan antara populasi kutu kebul (Bemisia tabaci Genn.) dan kejadian penyakit kuning pada tanaman cabai (Capsicum annumL.).Jurnal Agroekoteknologi FP USU. 5. (110): 847854.

Najah L N, Suhartanto M R \& Widodo. 2016. Pengendalian Colletotrichum spp. terbawa benih cabai dengan paparan gelombang mikro. J. Patologi Indonesia, 12 (4): 115 - 123.

Natawigena, H. 1993. Dasar-dasar perlindungan tanaman. Penerbit Trigenda Karya. Bandung.

Naylor M, Murphy AM, Berry JO, \& Carr JP. 1998. Salicylic acid can induce resistance to plant virus movement. Molecular Plant Microbe Interac. 11:860-866.

Nur Aeni, A. 2007. Kajian Kestabilan Produktivitas Cabai Keriting Di Daerah Endemis Virus Kuning dengan Optimalisasi Nutrisi Tanaman.Tesis. UGM.

Saguez J, Hainez R, Cherqui A, Van WO, Jeanpierre H, Lebon G, Noiraud N, Beaujean A, Jouanin L, Laberche J \& Vincent C.2005. Unexpected effect of chitinases on the peachpotato aphid (Myzus persicae Sulzer) 40 when delivered via transgenic potato plants (Solanum tuberosum Linne) and in vitro. Translational Research 14(1):57-67.

Siegel BZ. 1993.Plant peroxidases an organismic perspective.Journal Plant Growth Regulation. 12(3):303-312.

Souza IRPD, Oliveira ED, Peres MA, Oliveria ACD, Purcino AÁC.2003. Peroxidase activity in maize inbred lines resistant or susceptible to Maize dwarf mosaic virus.Rev Brasil Milho Sorgo.2(1):1-8.

Stermer BA. 1995.Molecular regulation of systemic induced resistance. in: Induced Resistance to Disease in Plant.(R Hammerschmidt, and J Kuc, Eds.). Kluwer Academic Publisher, Dordrecht.

Taufik M, Sarawa A, Hasan K \& Amelia. 2013. Analisis pengaruh suhu dan kelembapan terhadap perkembangan penyakit Tobacco mosaic virus pada tanaman cabai. Jurnal Agroteknologi. Universitas Haluoleo.

Trisno J, Sri HH., \& Ishak M. 2010. Hubungan strain Geminivirus dan serangga vektor B. Tabaci dalam menimbulkan penyakit kuning keriting cabai. Manggaro.11(1):1-7.

Tuhumury G N C \& Amanupunya H R D. 2013. Kerusakan tanaman cabai akibat penyakit virus di desawaimital kecamatan kairatu. Jurusan Budidaya Jl. Ir. M Putuhena, kampus Poka, Ambon\2(1): 36-42

Turk JE, Breda C, Buffard C, Sallaud C, Esnault RS \& Kondorosi A. 1993. Analysis of Peroxidase Gene Expression in an Hypersensitive Response Induced by Pathogenic Bacteria on Alfalfa. Kluwer Academic Publisher, Dordrecht.

Vanloon LC, Pierpoint WS, Boller TH \& Conejero V. 1994. Recommendations for naming plant phatogenesis related proteins. Plant Molecular Biology Report. 12 : 245-264.

Yuliani PH. \& Dewi S. 2006. Identifikasi Kutu kebul (Hemiptera: Aleyrodidae) dari Beberapa Tanaman Inang dan Perkembangan Populasinya. J.Entomol. Ind.3(1): 41-49.

Zeng D, Luo X, Tu R. 2012. Application of bioactive coatings based on chitosan for soybean seed protection. International Journal of Carbohydrate Chemistry 20(12):1-5.

Zhang MI, Tan T, Yuan H, Rui C. 2003. Insecticidal and fungicidal activities of chitosan and oligochitosan.Journal of Bioactive and CompatiblePolymers.18:391-400.

Zhou BW, Liu L, Chen DY, Yu Q, Yang J, and Wang C. 1992. Peroxidase in relation to varietal resistance to virus disease in rapeseed (Brassica napus). Oil Crops of China $2: 52-54$. 